\title{
Doctors do not use the medical microbiology laboratory when infectious diseases are suspected
}

\author{
${ }^{1}$ Lawson, S., and ${ }^{2}$ Omunakwe, H. E. \\ Departments of ${ }^{1}$ Medical Microbiology and Parasitology, and ${ }^{* 2}$ Haematology and Blood Transfusion, \\ River State University Teaching Hospital, Port Harcourt, Nigeria \\ *Correspondence to: hannahomunakwe@gmail.com
}

Copyright 2021 AJCEM Open Access. This article is licensed and distributed under the terms of the Creative Commons Attrition 4.0 International License $<$ a rel="license" href="http://creativecommons.org/licenses/by/4.0/", which permits unrestricted use, distribution and reproduction in any medium, $<\mathrm{a}$ rel="license" href $=$ "http://creativecommons. org/licenses/by/4.0/", which permits unrestricted
provided credit is given to the original author(s) and the source. Editor-in-Chief: Prof. S. S. Taiwo

\section{Les médecins n'utilisent pas le laboratoire de microbiologie médicale en cas de suspicion de maladies infectieuses}

\author{
${ }^{1}$ Lawson, S., et ${ }^{2}$ Omunakwe, H. E. \\ Départements de ${ }^{1}$ Microbiologie Médicale et Parasitologie, et $* 2$ Hématologie et Transfusion Sanguine, \\ Hôpital Universitaire de River State, Port Harcourt, Nigéria \\ *Correspondance à: hannahomunakwe@gmail.com
}

Dear Editor,

There has been a lot of talk in recent years about infection prevention and control, rational use of antibiotics (1), antimicrobial stewardship (2), antimicrobial resistance and reports of multi-resistant organisms (3) from isolates in hospitalized patients. Looking at the body of evidence available, we took a survey of doctors, their prescription patterns, request for microbiological investigations before prescription and some of the things that informed their decisions when treating patients suspected to have infections.

Of the 198 doctors in Port Harcourt, Nigeria who responded to the online survey between July and October 2019, 149 (75.3 \%) had been in practice for more than 10 years, the majority working in government facilities, and $101(52.3 \%)$ were physicians in various sub-specialities. Majority of the respondents $191(98.9 \%)$ prescribed antibiotics; $83(43 \%)$ prescribed daily while $51(26.4 \%)$ prescribed 'occasionally'. Thirty-one respondents (16.1\%) 'occasionally' request for microbiology laboratory input while 100 (51.8\%) 'sometimes' request for microbiological tests before prescribing antibiotics, and only 8 (4.2\%) 'always' request for microbiological tests before prescribing antibiotics.

The commonest reasons for not requesting for microbiological tests were the long turn-around-time in $93(50.5 \%)$, and the fact that they 'knew what drug to use' in 43 (23.4\%) using previously seen cases as guide. Some doctors had specific drugs they preferred to use in $41(22.3 \%)$ of the respondents. Interestingly some responded that the cost of microbiological tests was too high in $30(16.3 \%)$ respondents. A few 2 (1.1\%) however responded they did not request for these tests because they did not know how to collect the samples required. Interestingly too, many of the doctors were satisfied with the test menu provided by their medical microbiology laboratory at the time of the survey, while some doctors would have loved to have more tests done such as automated microscopy, culture and sensitivity, molecular tests for viruses (including viral haemorrhagic fevers) and serological tests for fungal infections.

The findings from this one-minute survey are quite revealing and takes us back to the undergraduate training of the doctor. We understand that antibiotics are very important weapons in the doctor's arsenal, there had been a steady rise in the range of available antibiotics and a concomitant rise in mutations and acquisition of resistance genes in microorganisms (4) thus making antibiotics ineffective over time and increasing morbidity and mortality in our patients. As doctors, we will need to think 'patient safety', and from training to practice, establish the ground rules for the rational use of antimicrobial agents. This responsibility lies in the hands of medical microbiologists, pharmacologists and every 


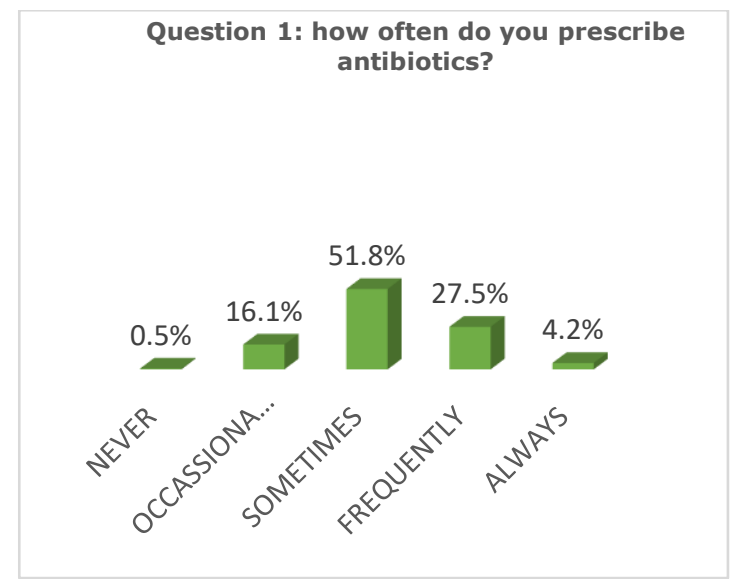

\begin{tabular}{|c|c|}
\hline Answer choices & Responses (\%) \\
\hline I know what drugs to use & 23.4 \\
\hline $\begin{array}{l}\text { There are antibiotics we prefer to use in } \\
\text { my team }\end{array}$ & 22.3 \\
\hline $\begin{array}{c}\text { The time to get results from the lab is too } \\
\text { long }\end{array}$ & 50.5 \\
\hline $\begin{array}{l}\text { The test result is not usually in sync with } \\
\text { clinical picture }\end{array}$ & 16.9 \\
\hline $\begin{array}{c}\text { I sometimes need the input of a } \\
\text { Consultant Microbiologist and there is } \\
\text { none }\end{array}$ & 6.5 \\
\hline $\begin{array}{c}\text { The microbiological tests are too } \\
\text { expensive }\end{array}$ & 16.3 \\
\hline $\begin{array}{l}\text { The staff are sometimes harsh to my } \\
\text { patients }\end{array}$ & 4.9 \\
\hline $\begin{array}{c}\text { I don't know how to collect some samples } \\
\text { for microbiological tests }\end{array}$ & 1.1 \\
\hline Other (please specify) & 35.87 \\
\hline
\end{tabular}

Fig 1: Responses from respondents on the frequency of prescription and use of the microbiology laboratory

doctor involved in training medical students. There is also a need to build capacity and interest in our young doctors, pharmacists and biomedical scientists so that we can do more in prompt diagnosis of infectious diseases and be better stewards of antibiotics.

One of the things that may drive inappropriate use of antibiotics in our setting is the 'corridor consultation', where doctors and 'non-medics' prescribe medications for symptoms described by patients on phone without any physical examination and/or laboratory evaluation (5). Indiscriminate empirical prescription of antibiotics without appropriate laboratory investigation should be discouraged in this era of antimicrobial resistance, and antibiotic stewardship should be promoted in every sphere of medical education and service. Some of the responses to $\mathrm{Q} 1$ as shown in Fig 1 are not acceptable in this era of antimicrobial stewardship. Healthcare managers, consultants in different specialities of medicine and laboratory managers must take steps to fill these gaps and make better use of the medical microbiology services.

\section{References:}

1. Kourkouta, L. The Rational Use of Antibiotics Medicine. Journal of Healthcare Communications 2017; 2: 1-4.

2. Morency-Potvin, P., Schwartz, D. N., and Weisstein, R. A. Antimicrobial Stewardship: How the Microbiology Laboratory Can Right the Ship. Clin Microbiol Rev. 2016; 30 (1): 381-407. doi: 10.1128/CMR.00066-16

3. Onanuga, A., Mahindroo, J., Singh, S., and Taneja, N. Phenotypic and molecular characterization of antimicrobial-resistant Escherichia coli from urinary tract infections in Port-Harcourt, Nigeria. Pan Afr Med J. 2019; 34: 144. doi:10.11604/pamj.2019.34.144.18182

4. Fair, R. J., and Tor, Y. Antibiotics and bacterial resistance in the 21 st century. Perspect Medicin Chem. 2014: doi: 10.4137/PMC.S14459

5. Muhammad, G. A. A. Corridor consultations: Should this practice be discouraged? J Pak Med Assoc. 2010; 60 (8): 694 - 695 